\title{
COMPARATIVE STUDY ON THE CORROSION RESISTANCE OF SPECIMENS FROM NON-MODIFIED AND NANO-MODIFIED STEEL GX120Mn12
}

\author{
VANYA Dyakova ${ }^{*}$ and YoAnna Kostova \\ Institute of Metal Science, Equipment and Technologies \\ with Hydro- and Aerodynamics Centre "Acad. Angel Balevski", \\ Bulgarian Academy of Sciences, \\ 67, Shipchenski Prohod Blvd, 1574 Sofia, Bulgaria, \\ e-mails:v_diakova@mail.bg; joanna_hristova@abv.bg
}

The corrosion behavior of specimens of steel grade GX120Mn12 before and after nano-modification with a composition of $\mathrm{TiCN}+\mathrm{Y}_{2} \mathrm{O}_{3}+\mathrm{Cr}+\mathrm{Fe}$ in ratio 2:1:1:6 is studied. The method of cyclic immersion in different aggressive media such as solution of $\mathrm{NaCl}, \mathrm{MgCl}_{2}$ and $\mathrm{MgSO}_{4}$, and $3 \% \mathrm{NaCl}$ is used. The indicators for mass loss and average corrosion rate are determined at every 50 hours of the test. It has been found that the corrosion resistance of the nano-modified specimens is improved in comparison with the one of the non-modified ones during the first fifty test hours of the cyclic immersion in both environments.

Keywords: nano-modified steel corrosion, nano-modifiers, GX120Mn12.

\section{INTRODUCTION}

The increased requirements to the fabricated metal products demand using metallic materials with improved properties for their production. Steels are the foundation of all construction and infrastructure facilities, automobiles, ships, tools and other industrial products. Until recently the properties of the steels are improved mainly by alloying with other elements or by selecting appropriate heat treatment modes.

One of the advanced techniques used to improve the properties of metallic materials during the last decade is the introduction of nano-sized particles of refractory compounds into the metal melts $[1,2]$. It was found that modification with nano-sized particles results in a more uniform and homogeneous structure of metals. Depending on the type of nano-modifier the strength, ductility or wear resistance of the metals can be improved $[3,4]$.

\footnotetext{
${ }^{*}$ Corresponding author.

DOI: 10.7546/EngSci.LV.18.01.05
}

(c) Инженерни науки, год. LV, 2018, № 1

61

(C) Engineering Sciences, LV, 2018, No. 1 
The impact of nano-modification on the mechanical properties of ironcarbon compounds is the subject of many studies [5, 6], but the published data from corrosion resistance tests of these alloys is still insufficient.

This paper presents the results from the corrosion resistance test of pieces of cast parts for excavation of aggregates from the riverbed made of either non-modified or nano-modified steel grade GX120Mn12 in different corrosive environments.

\section{EXPERIMENTAL}

\subsection{Tested materials}

Two types of specimens of steel GX120Mn12 are tested. The chemical composition of the steel is given in Table 1 .

TABLE 1

\begin{tabular}{|c|c|c|c|c|c|c|c|c|}
\hline \multirow{2}{*}{ No } & & \multicolumn{7}{|c|}{ Chemical composition [\% $\mathrm{wt}]$} \\
\cline { 3 - 9 } & & $\mathrm{C}$ & $\mathrm{Si}$ & $\mathrm{Mn}$ & $\mathrm{Cr}$ & $\mathrm{Ni}$ & $\mathrm{S}$ & $\mathrm{P}$ \\
\hline 1 & $\begin{array}{c}\text { Steel } \\
\text { GX120Mn12 }\end{array}$ & $1.1 \div 1.3$ & $\leq 0.50$ & $11.5 \div 13.5$ & $\leq 1$ & - & 0.02 & 0.01 \\
\hline
\end{tabular}

The first type of specimens labeled with A are taken from parts made of Non-Modified (NM) steel and the second type of specimens labeled with B are taken from Modified Steel (MS) castings obtained in laboratory conditions in induction furnace at temperature $1530-1550{ }^{\circ} \mathrm{C}$. The used Modifying Composition (MC) consists of 2 fractions $\mathrm{TiCN}+1$ fraction $\mathrm{Y}_{2} \mathrm{O}_{3}+1$ fraction $\mathrm{Cr}+6$ fractions Fe. TiCN and $\mathrm{Y}_{2} \mathrm{O}_{3}$ are nanoscale powders, $\mathrm{Cr}$ and $\mathrm{Fe}$ are micronized powders and serve as a plaque coating. The MC is introduced into the melt packed in aluminum foil and placed in a container. After the container melts the MC falls into the liquid metal. The homogenization of MC within the volume of the melt occurs in result of its convective motion induced by the electromagnetic field generated by the furnace inductor. The stirring of the metal during pouring from the furnace into the casting ladle contributes additionally for the homogenization too [7].

The total amount of the modifier is $0.025 \%$ by mass of the total steel composition. The composition of the modifier is selected to improve the mechanical properties of the material, such as hardness, strength and wear resistance.

Before cutting out the spesimens the steel parts are subjected to heat treatment consisting in heating to $600{ }^{\circ} \mathrm{C}$ at a rate of $150{ }^{\circ} \mathrm{C} / \mathrm{h}$ subsequent heating

(c) Инженерни науки, год. LV, 2018, № 162 (c) Engineering Sciences, LV, 2018, No. 1 
from $600{ }^{\circ} \mathrm{C}$ to $1050-1080{ }^{\circ} \mathrm{C}$ at a rate of $200{ }^{\circ} \mathrm{C} / \mathrm{h}$, holding for 40 minutes, and quenching in water.

\subsection{Test method}

The accelerated model corrosion tests are carried out according to the method of cyclic immersion in corrosion medium and subsequent drying. The cyclic method is prefered to the usual continuous immersion because of the more aggressive corrosive effect of the medium due to the alternation of immersion and drying times.

To assess the impact of the corrosion environment on modified and nonmodified steels, medium with different chemical compositions and corrosion aggressiveness is used. The compositions of the medium are chosen similar to the compositions of the working environments in which the parts actually operate. Medium No. 1 is an aqueous solution of $\mathrm{NaCl}, \mathrm{MgCl}_{2}$, and $\mathrm{MgSO}_{4}$ (ground water), and medium No. 2 is a $3 \% \mathrm{NaCl}$ solution. The main component of the two media are the chlorine ions $\left(\mathrm{Cl}^{-}\right)$, but medium No. 1 is more aggressive because it contains both sulphate $\left(\mathrm{SO}_{4}^{2-}\right)$ and chlor ions $\left(\mathrm{Cl}^{-}\right)$.

The total duration of the test is 350 hours. The immersion/drying cycle is repeated with a preset frequency for a certain period of time. The ratio of the durations of immersion and drying is 1:2. During the test the air temperature is $(27+1){ }^{\circ} \mathrm{C}$, the temperature of the solutions is $(25+1)^{\circ} \mathrm{C}$, and the acidity of the solutions is $\mathrm{pH}=5.5$ and $\mathrm{pH}=2$ for medium No. 1 and No. 2, respectively. The mass loss $\Delta \mathrm{m}\left[\mathrm{g} / \mathrm{m}^{2}\right]$ and the average corrosion rate $\mathrm{K}\left[\mathrm{g} / \mathrm{m}_{2} \mathrm{~h}\right]$ of each test specimen are determined every 50 hours during the first 200 test hours.

Metallographic analysis of the steel structure GX120Mn12 in non-modified and nano-modified state before and after the corrosion tests is performed using optical microscope JENAVERT of Carl Zeiss.

\section{RESULTS AND DISCUSSION}

\subsection{Microstructure of GX120Mn12 before the corrosion test}

After the heat treatment the microstructure of the specimens of both modified and non-modified steel GX120Mn12 has austenitic structure with carbides deposited internally and along the grain boundaries. The size of the carbides in the non-modified steel is predominantly in the range from $3 \mu \mathrm{m}$ to $50 \mu \mathrm{m}$, Fig. 1 $(a, b)$. The size of the carbides in the modified steel is in the range from $3 \mu \mathrm{m}$ to $40 \mu \mathrm{m}$, Fig. 1( $c, d$ ), but carbides much larger in size (up to $15 \mu \mathrm{m}$ ) are also observed. Apart from the reduction of the average size of carbides, after

(C) Инженерни науки, год. LV, 2018, № 1

63

(C) Engineering Sciences, LV, 2018, No. 1 
the modification some redistribution of the carbides in different grain areas is also observed. It should be noted that the larger carbides in the modified specimens are located on or near the grain boundaries, Fig. 1(d).

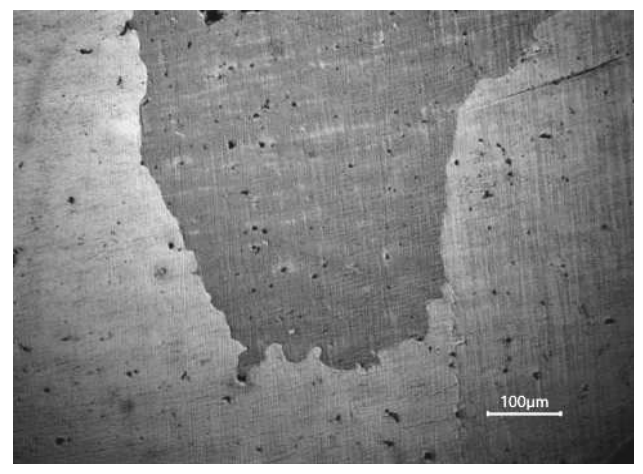

(a)

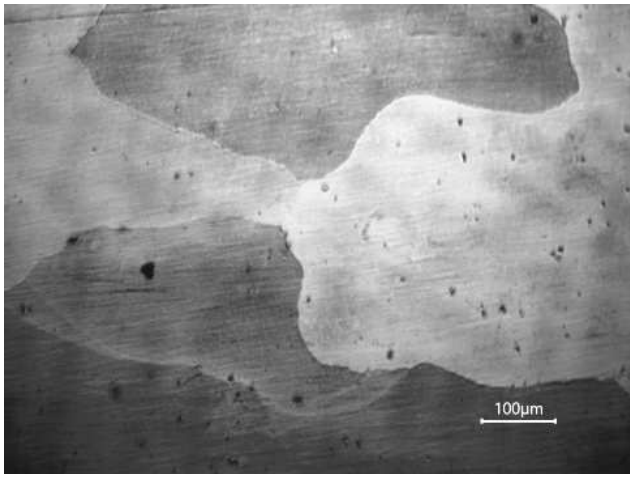

(c)

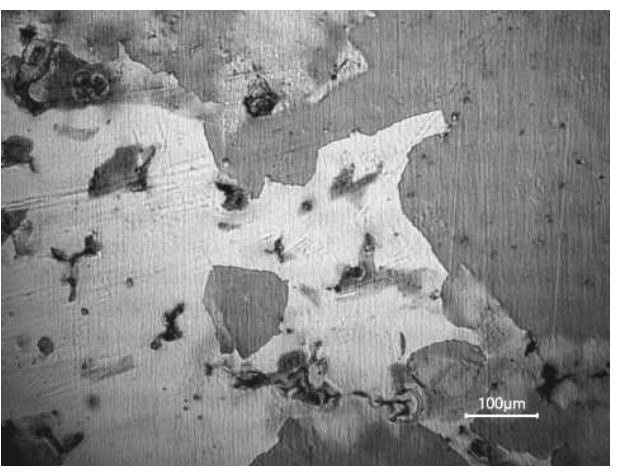

(b)

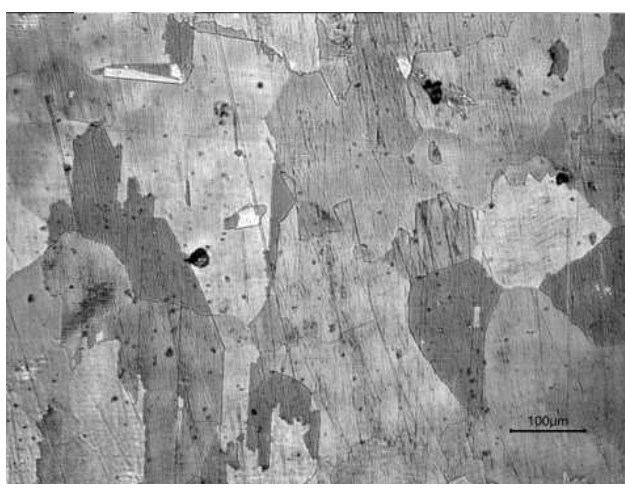

(d)

Fig. 1. Initial structures of the tested specimens of steel GX120Mn12:

(a) and (b) non-modified specimens (A); (c) and (d) modified specimens (B)

\subsection{Results from the corrosion test}

The results from corrosion tests of the modified and non-modified specimens are given in Table 2. The values for the mass loss $\Delta \mathrm{m}$ and the corrosion rate $\mathrm{K}$ are the arithmetic mean of three tested specimens of each type.

Figure 2 shows the change of corrosion rate $\mathrm{K}\left[\mathrm{g} / \mathrm{m}^{2} \mathrm{~h}\right]$ with time for modified and non-modified steel specimens in both media.

The diagram shows that during the first 50-hours test period the corrosion rates of the non-modified specimens in both media are five times higher than

(c) Инженерни науки, год. LV, 2018, № 1 
TABLE 2

\begin{tabular}{|c|c|c|c|c|c|c|c|c|}
\hline $\begin{array}{c}\text { Speci- } \\
\text { men } \\
\text { No }\end{array}$ & \multicolumn{2}{|c|}{ After 50 hours } & \multicolumn{2}{|c|}{ After 100 hours } & \multicolumn{2}{c|}{ After 150 hours } & \multicolumn{2}{c|}{ After 200 hours } \\
\cline { 2 - 9 }$\left[\mathrm{g} / \mathrm{m}^{2}\right]$ & $\begin{array}{c}\Delta \\
{\left[\mathrm{g} / \mathrm{m}^{2} \mathrm{~h}\right]}\end{array}$ & $\begin{array}{c}\Delta \mathrm{m} \\
{\left[\mathrm{g} / \mathrm{m}^{2}\right]}\end{array}$ & $\begin{array}{c}\mathrm{K} \\
{\left[\mathrm{g} / \mathrm{m}^{2} \mathrm{~h}\right]}\end{array}$ & $\begin{array}{c}\Delta \mathrm{m} \\
{\left[\mathrm{g} / \mathrm{m}^{2}\right]}\end{array}$ & $\begin{array}{c}\mathrm{K} \\
{\left[\mathrm{g} / \mathrm{m}^{2} \mathrm{~h}\right]}\end{array}$ & $\begin{array}{c}\Delta \mathrm{m} \\
{\left[\mathrm{g} / \mathrm{m}^{2}\right]}\end{array}$ & $\begin{array}{c}\mathrm{K} \\
{\left[\mathrm{g} / \mathrm{m}^{2} \mathrm{~h}\right]}\end{array}$ \\
\hline A-1* & 20.671 & 0.413 & 8.167 & 0.119 & 13.134 & 0.263 & 0.194 & 0.004 \\
\hline $\mathrm{A}^{*} 2^{*}$ & 17.340 & 0.346 & 5.978 & 0.119 & 4.498 & 0.089 & 13.460 & 0.269 \\
\hline B-1 $^{*}$ & 3.958 & 0.0790 & 6.112 & 0.1224 & 8.069 & 0.1614 & 7.065 & 0.1413 \\
\hline B-2 $^{*}$ & 3.286 & 0.0657 & 4.668 & 0.0367 & 6.414 & 0.1283 & 16.316 & 0.3273 \\
\hline
\end{tabular}

* A and B mean non-modified and modified steel, accordingly, and 1 and 2 are the type of corrosion medium used.

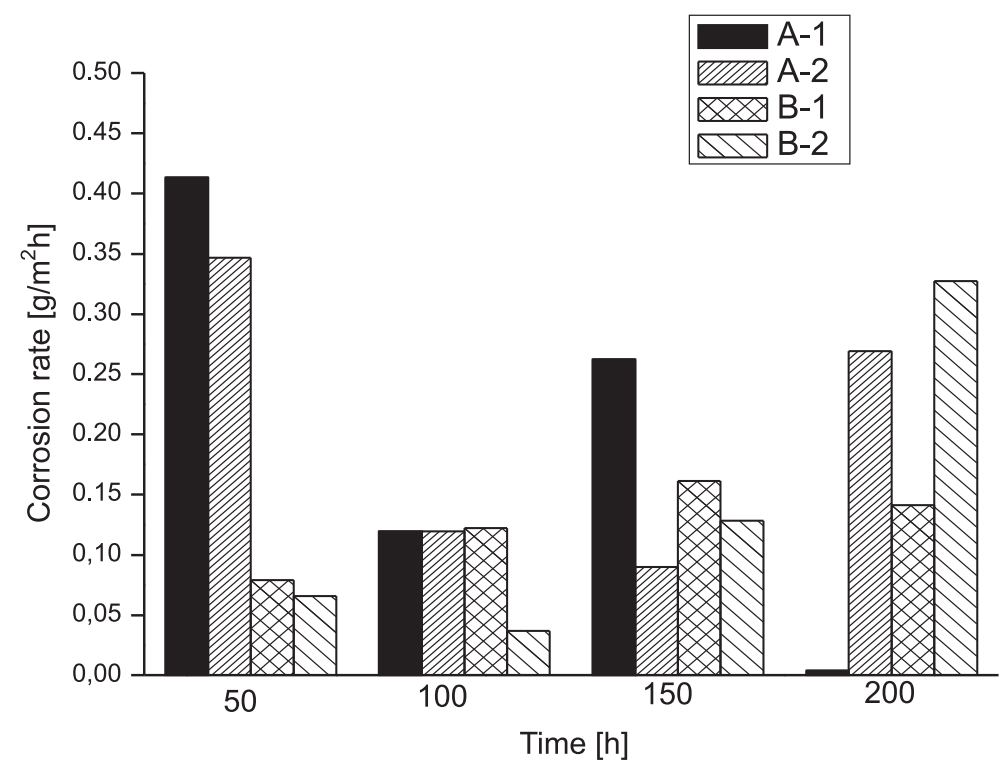

Fig. 2. Corrosion rate during the test

those in the modified ones. The corrosion rate $\mathrm{K}$ in medium No. 1 is higher than in medium No. 2. The results for the non-modified specimens are similar, and the explanation is the higher concentration of the aggressive $\mathrm{Cl}^{-}$and $\mathrm{SO}_{4}^{2-}$ ions in the solution. During this period of the test the surfaces of the samples are still clean, with no corrosion products formed and unlimited oxygen-tometal access, which facilitates the corrosion process and increases the rate of corrosion.

The microscope observation of the corroded surfaces shows the presence of single unevenly distributed pits.

(c) Инженерни науки, год. LV, 2018, № 165 (c) Engineering Sciences, LV, 2018, No. 1 
During the second 50-hours test period the corrosion rates of the nonmodified specimens in both media are $2 \div 2.5$ times lower than that during the first period due to the oxide layer formed on the surface of the specimens, which impedes the access of oxygen and the aggressive $\mathrm{Cl}^{-}$and $\mathrm{SO}_{4}^{2-}$ ions from the solution and slows down the corrosion process.

The corrosion rate $\mathrm{K}$ of the modified specimen $\mathrm{B}-1$ immersed in medium No. 1 is 1.5 times faster during the second period compared to the first period. However, for the modified specimen B-2 immersed in medium No. 2 the value of $\mathrm{K}$ is two times lower compared to the first period.

The data obtained for the third test period shows a sharp increase in the corrosion rate of the non-modified specimen (A-1) in medium No. 1 (ground water). The high value of the mass loss indicator gives evidence of active processes of general corrosion taking place.

In the modified samples an increase in the rate of corrosion in both media is observed as a consequence of the experimental conditions: a sequential impact of the aggressive ions in the solutions and of the oxygen in the air. The pits observed initially are increased in size and merged, and the corrosion layer covers the entire surface.

The data obtained for the fourth period of the study shows that corrosion rate of sample B-1 (modified in ground water) remains almost unchanged after the previous period, and the value of $\mathrm{K}$ of sample A-1 (non-modified) is close to zero, which means that the corrosion process slows down. The reason for attenuation is the formation of a dense layer of corrosion products during the third period, which impedes the access of the aggressive ions from the solution to the metal surface.

During the fourth period there is a sharp increase in the corrosion rate $\mathrm{K}$ of both types of specimens in medium No. $2(3 \% \mathrm{NaCl})$.

\subsection{Visual corrosion analysis after 350 hours of test}

Figure 3 shows the corroded surfaces of the samples after 350 hours of cyclic corrosion testing. It is obvious that the accumulated corrosion products have multiple layers with different morphology in all specimens.

The observed corrosion products have colours that are typical for oxidized iron $\left(\mathrm{Fe}^{+}\right)$, from lemon yellow, through light- and reddish brown, to dark brown. Some greenish-brown deposits are also observed. These are the colours of $\alpha$-FeOOH (geotitis), $\beta$-FeOOH, $\gamma$-FeOOH (lepidocrocyte), $\alpha-\mathrm{Fe}_{2} \mathrm{O}_{3}$ (hematite) $[8,9]$, and that assumption is confirmed by the X-ray diffraction analysis of the corrosion product. The reason for the formation of corrosion compounds is the easy oxidation of $\mathrm{Fe} 2^{+}$to $\mathrm{Fe} 3^{+}$in aqueous solution under

(c) Инженерни науки, год. LV, 2018, № 1 66 C) Engineering Sciences, LV, 2018, o. 1 


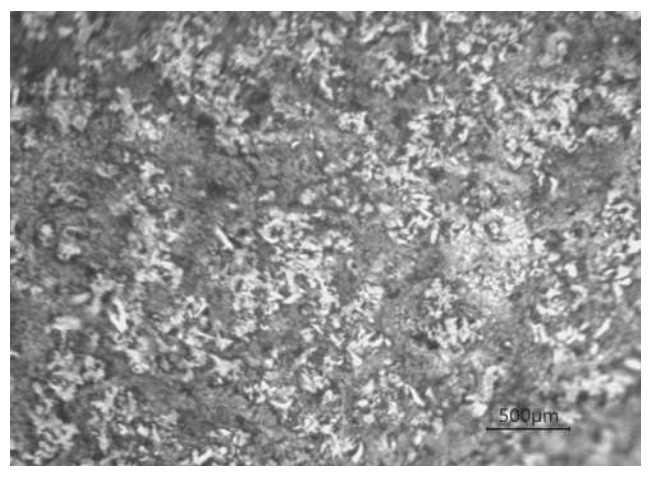

(a)

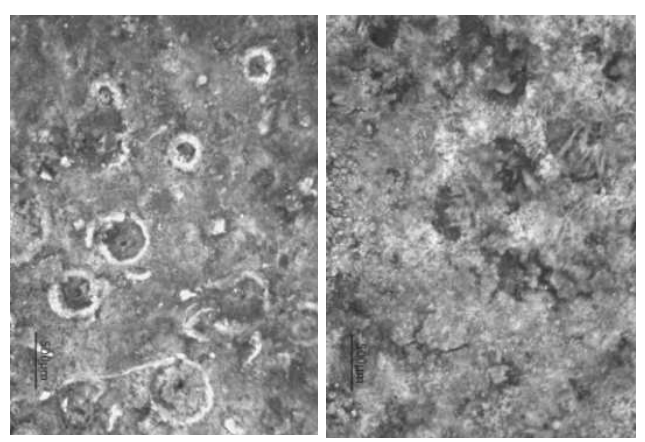

(c)

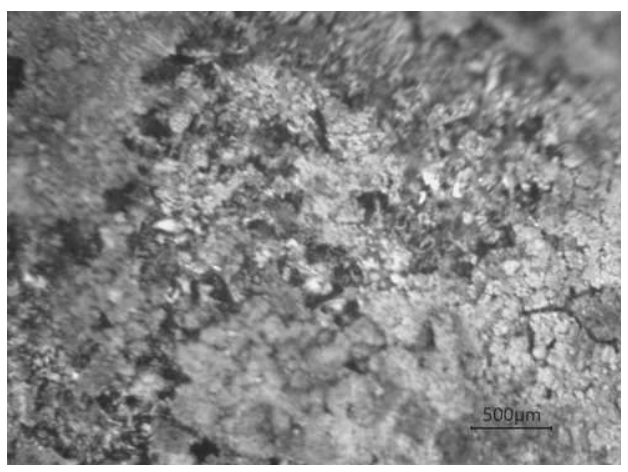

(b)

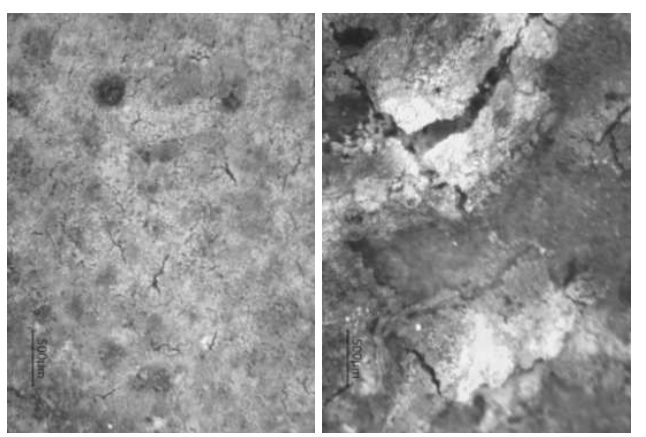

(d)

Fig. 3. Corrosion products depositsed on the surfaces of test specimens after 350 test hours: (a) corrosive surface of non-modified specimens, medium No. 1 (ground water); (b) medium No. $2(3 \% \mathrm{NaCl})$; (c) corrosive surface of modified specimens, medium No. 1 (ground water); (d) medium No. $2(3 \% \mathrm{NaCl})$

the influence of dissolved oxygen from the air. The formation of iron oxides and hydroxides is influenced by the presence of additional cations and anions in the solution.

The greenish-brown deposits observed in some areas of the surface and between the layers are the so-called "green rust". These are hydrated colored iron compounds containing $\mathrm{Cl}^{-}, \mathrm{SO}_{4}^{2-}$ or $\mathrm{CO}_{3}^{2-}$ ions, which are formed in highly humid environments with access of oxygen. The "green rust" is a transition phase and after subsequent oxidation transforms into the more stable phases $\alpha$-FeOOH and $\mathrm{Fe}_{3} \mathrm{O}_{4}$.

The accumulation of corrosion products on the surfaces of the specimens and the amount of iron added by means of the nano-modifier are some of the 
reasons for the change in corrosion rate over the later test periods. On the other hand, it is known that the addition of $\mathrm{Cr}$ enhances the susceptibility to intercrystalline corrosion, and $\mathrm{Cr}$ is one of the elements in the composition of the nanomodifier used [10]. There is evidence for the influence of $\mathrm{Y}_{2} \mathrm{O}_{3}$ on the corrosion behavior of this type of steel. It is known that $\mathrm{Y}_{2} \mathrm{O}_{3}$ increases the corrosion resistance and prevents the rapid corrosion attack in aggressive environment $[2,3]$. The improved corrosion resistance of specimens coated with $\mathrm{Y}_{2} \mathrm{O}_{3}$ is due to the formation of the complex compound $\mathrm{FeY}_{2} \mathrm{O}_{4}$, which acts as a grain boundary barrier and prevents the migration of cations and anions [11]. It has been found that the increased percentage of TiCN significantly stimulates the corrosion process [12].

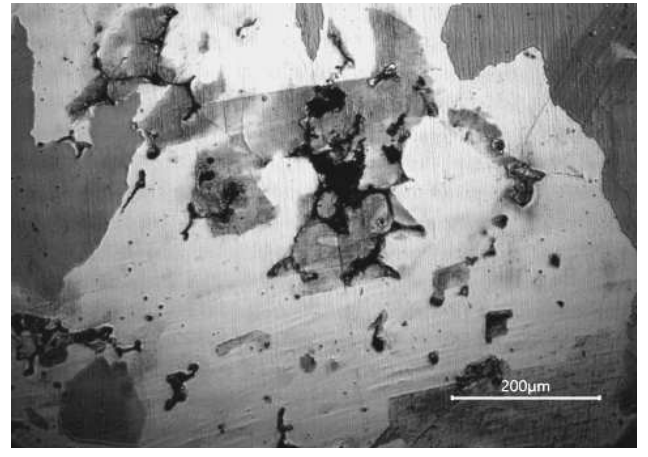

(a)

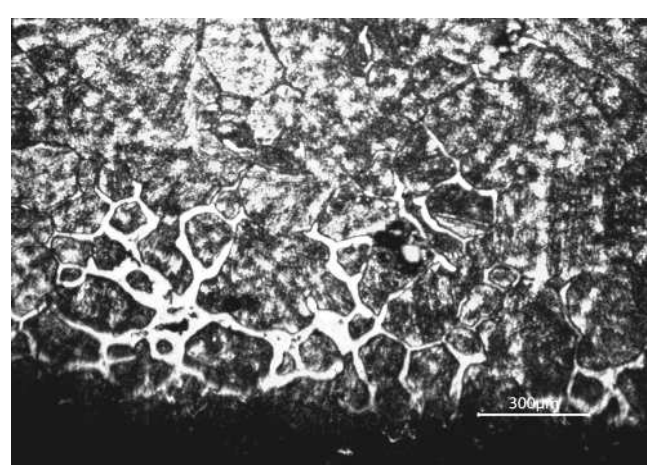

(c)

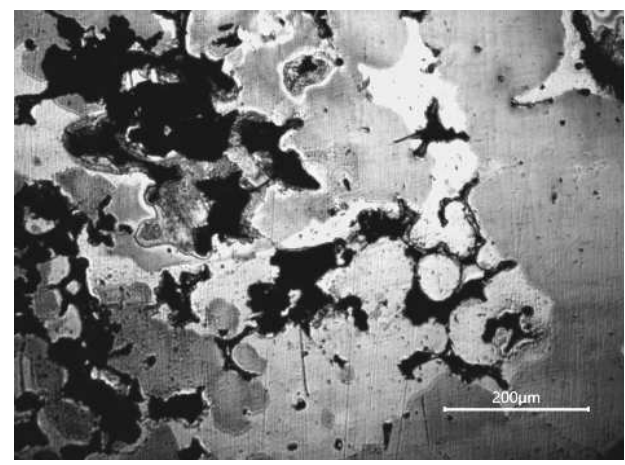

(b)

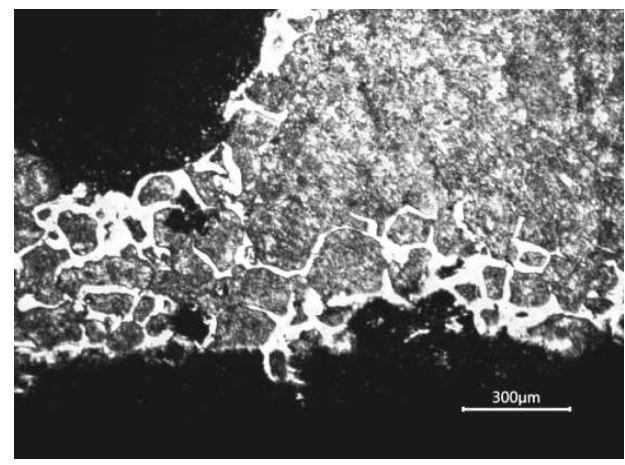

(d)

Fig. 4. Development of intergranular corrosion after 350 hours of corrosion test: (a) non-modified specimens, medium No. 1 (ground water); (b) medium No. 2 $(3 \% \mathrm{NaCl}) ;(\mathrm{c})$ modified specimens, medium No. 1 (ground water); (d) medium No. 2 $(3 \% \mathrm{NaCl})$ 
The metallographic study found evidence of intergranular corrosion in both modified and non-modified specimens after the corrosion test in both media. In the modified specimens, the intergranular corrosion occurs at an earlier test stage, i.e. after the $250^{\text {th }}$ hour, and in the non-modified ones it occurs after the $300^{\text {th }}$ to $350^{\text {th }}$ hour. In the specimens immersed in medium No. 1 (ground water) the intergranular corrosion is better expressed, Fig. 4(a, c), whereas in the specimens immersed in medium No. $2(3 \% \mathrm{NaCl})$ it is less pronounced, Fig. $4(b, d)$. The results for the non-modified specimens are similar but here the intergranular corossion covers smaller areas, Fig. 4( $a, b)$.

The occurrence and development of intergranular corrosion is typical for steels undergone structural changes, e.g. separation of new phases along the grain boundaries. In addition to the structural refinement after modification of steel GX120Mn12, increased amount of chromium carbides along the grain boundaries and reduced concentration of $\mathrm{C}$ and $\mathrm{Cr}$ in the surrounding areas are also observed during the present study. The further growth of the $\mathrm{Cr}$ carbides takes place on account of $\mathrm{C}$ from the solid solution, and only the $\mathrm{Cr}$ around the boundaries participates in the carbidation reaction. This is the reason for the appearance of Cr-depleted areas around the grain boundaries and hence the reduction of corrosion resistance, which results in appearance of intergranular corrosion.

\section{CONCLUSION}

- The data on the development of corrosion process in both non-modified and nano-modified specimens of steel grade GX120Mn12 obtained by determining the indicators for the mass loss and the average corrosion rate shows improved corrosion resistance of the nano-modified specimens during the initial test periods, i.e. the first one hundred hours.

- After one hundred hours of cyclic corrosion test the specimens of steel GX120Mn12 modified with $0.25 \%$ composition of TiCN $+\mathrm{Y}_{2} \mathrm{O}_{3}+\mathrm{Cr}+$ Fe in proportion 2:1:1:6 show a greater susceptibility to development of intergranular corrosion compared to the specimens of non-modified steel in both media (ground water and $3 \% \mathrm{NaCl}$ ).

- The modifier $\mathrm{TiCN}+\mathrm{Y}_{2} \mathrm{O}_{3}+\mathrm{Cr}+\mathrm{Fe}$ in proportion 2:1:1:6 introduced to improve the mechanical properties of steel grade GX120Mn12 has not a positive impact on its corrosion resistance.

(c) Инженерни науки, год. LV, 2018, № 1 


\section{REFERENCES}

[1] V. P Saburov, E. N. Eremin, A. N. Cherepanov and G. N. MinNEKHANOV, Modification of steels and alloys by dispersed inoculators, OmSTU Publishers Omsk (2002) (in Russian).

[2] S. N. Reshetnikova, Application of nanopowders of chemical compounds to improve physical and mechanical characteristics of engineering products, Abstract of the thesis for obtaining the scientific degree of Cand. Tech. Sci., Siberian State Aerospace University named after Academician M. F. Reshetnev, Institute of Computational Modeling SB RAS, Krasnoyarsk (2008) (in Russian).

[3] Z. A. Konotaeva, Manufacture of ultradispersed powders by mechanochemical method and their application for the modification of materials, Abstract of the thesis for obtaining the degree the scientific degree of Cand. Chem. Sci., Institute of Solid State Chemistry and Mechanochemistry of SB RAS., Novosibirsk (2008) (in Russian).

[4] V. A. Poluboyarov, A. N. Cherepanov, Z. A. Korotaeva and E. P. Ushakova, Method of increasing the corrosion resistance of cast irons, Patent application No. 2007106678/02 (007243) of 21.02.2007 (in Russian).

[5] Sung-Mo Hong, Jin-Ju Park a,n, Eun-Kwang Park a,c, Min-Ku Lee A, Chang-Kyu Rhee a, Jin Kyu Lee B, Jung Gu Lee D, Kyeong Ho KIM. Cavitation erosion behavior of SA 106B carbon steel after treatment of the melt with nano-sized TiC particles, Nuclear Materials Development Division, Korea Atomic Energy Research Institute, Daejeon 305-353, Republic of Korea, Tribology International (2015) 92 585-594.

[6] A. N. Baranov, E. A. Gusaev and E. M. Komova, Investigation of the corrosion resistance of steels traded for the manufacture of dredging equipment for gold mining, Systems, Methods, Technologies (2014) 1 (21) 102-106 (in Russian).

[7] P. Kuzmanov, R. Dimitrova, R. Lazarova, A. Cherepanov and V. MANOLOV, Investigations of the structure and mechanical properties of castings of aloy AlSi7Mg, cast iron GG15 and GG25 and steel GX120Mn12, modified by nanosized powders, Journal of Nanoengineering and Nanosystems (2014) 228 (1) $11-18$.

[8] Katsuya Inoue, Sang-Koo Kwon, Kenichi Kimijima and Kiyoshi Kanie, Analysis of Iron Oxyhydroxides and Oxides Converted from Green Rust in Aquaeus Solution, ISIJ International (2007) 47 (3) 453-457.

[9] Futoshi Nagata, Katsuya Inoue, Kozo Shinoda and Shigeru Suzuki, Characterization of Formation and Oxidation of Green Rust $\left(\mathrm{Cl}^{-}\right)$Suspension, ISIJ International (2009) 49 (11) 1730-1735.

[10] V. Chigal, Intercrystalline Corrosion of Stainless Steels, Khimiya Publishing House (1969) (in Russian).

(c) Инженерни науки, год. LV, 2018, № 1 
[11] D. Ghosh And S. K. Mitra-J, Effect of $\mathrm{Y}_{2} \mathrm{O}_{3}$ Superficial Coating on the High Temperature Corrosion Behavior of $2.25 \mathrm{Cr}-1 \mathrm{Mo}$ Steel in $\mathrm{SO}_{2}+\mathrm{O}_{2}$ Atmosphere, Inst. Eng. India Ser. D (October 2012-March 2013) 93 (2) 59-63.

[12] Ashok Kumar Srivastava, Karabi Das and Sandeep Kr. Toor, Corrosion behavior of TiC-Reinforced Hadfield Manganese Austenitic Steel Matrix In-situ Composites, Open Journal of Metal (2015) 5 11-17.

\title{
СРАВНИТЕЛНО ИЗСЛЕДВАНЕ НА КОРОЗИОННАТА УСТОЙЧИВОСТ НА ОБРАЗЦИ ОТ НЕМОДИФИЦИРАНА И НАНОМОДИФИЦИРАНА CTOMAHA GX120Mn12
}

\author{
ВАнЯ ДяковА И ЙоАннА КостовА
}

Институт по металознание, сгорбжения и технологии с Центор по хидро- и аеродинамика „Акад. Ангел Балевски“, Българска академия на науките, бул. Шипченски проход № 67, 1574 София, Бглгария, e-mail:v_diakova@mail.bg; joanna_hristova@abv.bg

Резюме. Изследвано е корозионното поведение на образци от стомана GX120Mn12 преди и след нейното модифициране посредством модификатор със състав $\mathrm{TiCN}+\mathrm{Y}_{2} \mathrm{O}_{3}+\mathrm{Cr}+\mathrm{Fe}$ в съотношение 2:1:1:6. Използван е методът на циклично потапяне в среди с различна агресивност - разтвор на $\mathrm{NaCl}, \mathrm{MgCl}_{2}$ и $\mathrm{MgSO}_{4}$ и $3 \% \mathrm{NaCl}$. Определени са показателите - загуба на маса и средна скорост на корозия, на всеки 50 часа от изпитването. Установено е, че корозионната устойчивост на модифицираните образци е подобрена в сравнение с тази на немодифицираните такива при първите петдесет часа от изследването на циклично потапяне и в двете среди.

Ключови думи: корозия на наномодифицирана стомана, наномодификатори, GX120Mn12. 